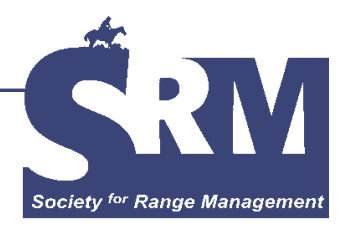

\title{
Saving the Ranch: Fresh Eyes on Taxes, Development, and Conservation Easements
}

\section{Conservation easements provide a surprising diversity of alternative strategies for maintaining the ranch.}

\section{By John B. Wright and Anthony Anella}

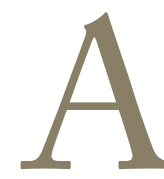

t some time every ranch family must decide either to stay in agriculture or sell the ranch. This decision may be driven by family situation or priorities as well as by economic and other forces largely outside the family's control. There is a tipping point when the weight of economic and personal considerations decides the future of a property ${ }^{1,2}$ (Fig. 1). That point is different in every case, and most families are used to thinking that they only have 2 choices - ranching or development. Although housing developments seem inevitable for rangelands in some urbanizing areas, most range managers like to see rangelands remain in sustainable management for agricultural production and natural resource values. What do we have to offer ranching families facing difficult choices? The answer can sometimes be found in partnership with conservation groups and agencies.

Land trusts and national conservation groups walk a delicate political and ethical line with agricultural landowners. While many praise ranchers for their range management and stewardship, others loudly write them off as destroyers of nature. What is lost in all this shouting is a plain fact-when ranchers go out of business, the land and its wildlife habitat, natural resources, open space, and history are lost to development. While conservation easements and the purchase of development rights are widely accepted tools for negotiating the middle ground - for saving the ranch - there are still leaps of faith to be made by people who should be natural allies. For-

This article has been peer reviewed.
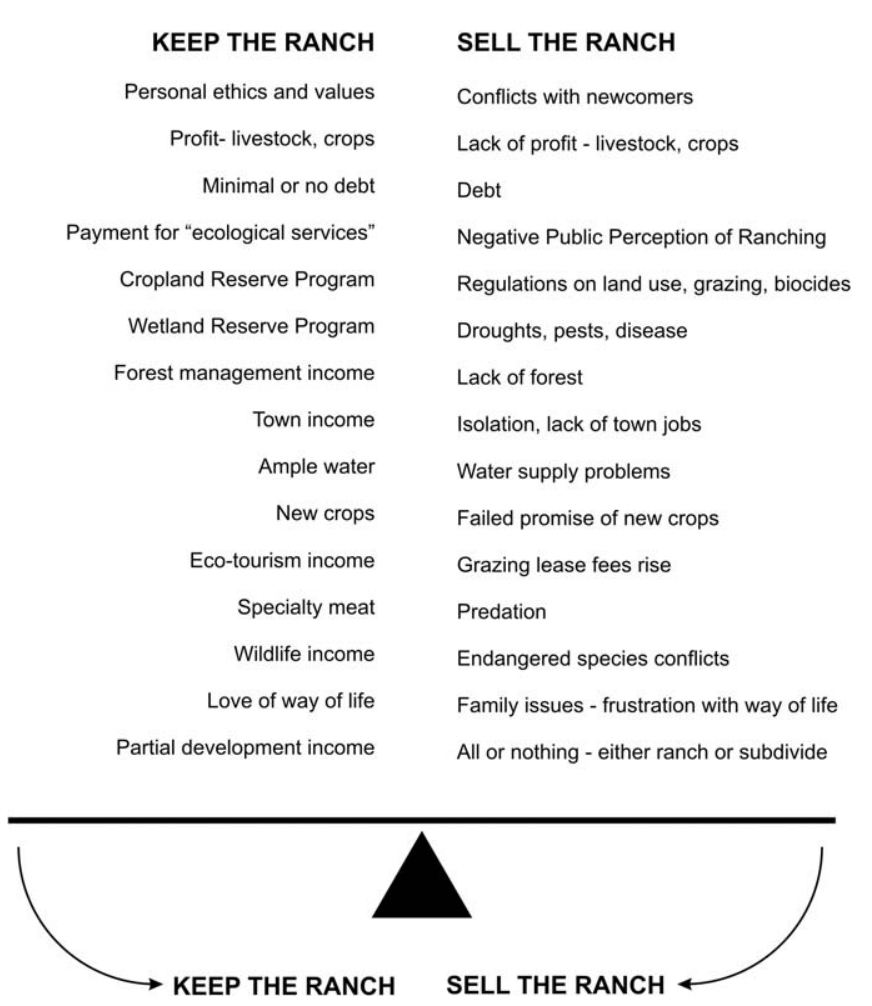

Figure 1. Many factors weigh in when a ranch family is faced with making a decision about the future of the ranch. Economics, environmental, social, and family issues all influence the decision and can tip the balance either way. 
Table 1. Running the Numbers

The following examples show how easement deductions come out.

Example 1-without a conservation easement

\begin{tabular}{|l|l|}
\hline Adjusted gross income & $\$ 50,000$ \\
\hline Itemized deductions & $\$ 0$ \\
\hline Taxable income & $\$ 33,100$ \\
\hline Net federal tax due & $\$ 4,210$ \\
\hline Example 1-with a conservation easement, qualified ag owner, $\$ 500,000$ value of conservation easement donation \\
\hline Adjusted gross income & $\$ 50,000$ \\
\hline Itemized deduction & $\$ 50,000$ (for 10 years in a row) \\
\hline Taxable income & $-\$ 6,600$ \\
\hline Net federal tax due & $\$ 0$ \\
\hline Total federal income tax savings: $\$ 4,210 \times 10$ years $=\$ 42,100$ \\
\hline Example 2-using a $\$ 100,000$ adjusted gross income and the same easement facts \\
\hline Total federal income tax savings: $\$ 13,890 \times 5$ years $=\$ 69,450$ \\
\hline
\end{tabular}

tunately, programs are emerging that bring agriculturalists and conservation groups together based on respect for rural culture and customs, the ecosystem benefits of ranching, and private property rights.

Ranchers are familiar with Farm Bill incentives for conservation practices on the 525 million acres of rangelands in the United States. The Conservation Reserve Program of the Natural Resources Conservation Service (NRCS) has 32 million acres enrolled. The Wetland Reserve Program has 16 million acres under conservation easements that prohibit construction. The Environmental Quality Incentives Program, the Grassland Reserve Program, and the Federal Farm and Ranch Lands Protection Program are examples of other federal incentives for private rangeland conservation. Yet some operators are still unclear or suspicious about conservation easements. Rangeland managers working to conserve private rangelands need to know as much as possible about how conservation easements and other incentive programs work.

\section{Landownership and Conservation Easements}

In the landownership "bundle of rights," water rights, timber rights, and mineral rights can be separated from the title to land. Development rights - the right to subdivide and develop private property - can also be separated from the land title and sold, traded, or donated. The basic idea of a conservation easement is to voluntarily donate or sell some or all of your development rights to a nonprofit land trust selected by the landowner-forever. This keeps the land from being subdivided, mined, or developed in ways that reduce its productive capacity as rangeland. The rancher still owns the land, pays "ag" property taxes on it, ranches it, leaves it to the children and/or sells it for whatever price someone will pay. If the rancher doesn't own the mineral rights, he or she may still be able to receive tax benefits for an easement donation if there is little likelihood of commercial mineral development.

\section{Land Trusts and Conservation Easements}

The first land trust in America was founded in 1890 as the “Trustees of Reservations in Massachusetts." As of 2005, there were 1,667 local and statewide land trusts, a 32\% increase since 2000. These groups have conserved over 12 million acres - the majority of it using voluntary conservation easements. The West contains $44 \%$ of the total and is showing the fastest growth in private land conservation. National conservation groups like the American Farmland Trust and The Nature Conservancy have worked with landowners to conserve another 25 million acres. Some land trusts are proagriculture, others are not. The Colorado Cattlemen's Association Agricultural Land Trust holds conservation easements on over 200,000 acres. The California Rangeland Trust has over 200,000 acres under easement, including the 80,000-acre Hearst Ranch. The combined actions of Malpai Borderlands Group (a rancher land trust), the Animas Foundation, and The Nature Conservancy have resulted in over 420,000 acres of rangeland easements along the New Mexico-Arizona border. The Montana Land Reliance has the largest tally with 700,000 acres of ranchland protected. With the understanding that conservation easements must be voluntary, the tool is supported by the National Cattlemen's Beef Association, the American Farmland Federation, and many stockgrowers groups.

\section{Conservation Easements and Tax Incentives}

A conservation easement is a voluntary, less-than-fee-simple legal interest in land that limits development to protect sig- 
Retain life estate on home or ranch, new owner leases ranch back to you

\section{No Conservation Easements} prior to sale

\section{Conservation Easement prior to sale}

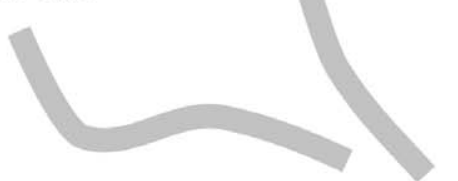

Sell to conservation buyer

No Conservation Easement prior to sale

Conservation Easement prior to sale

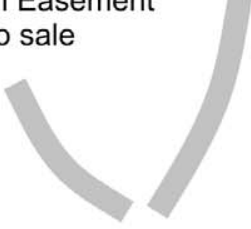

Sell to Rancher

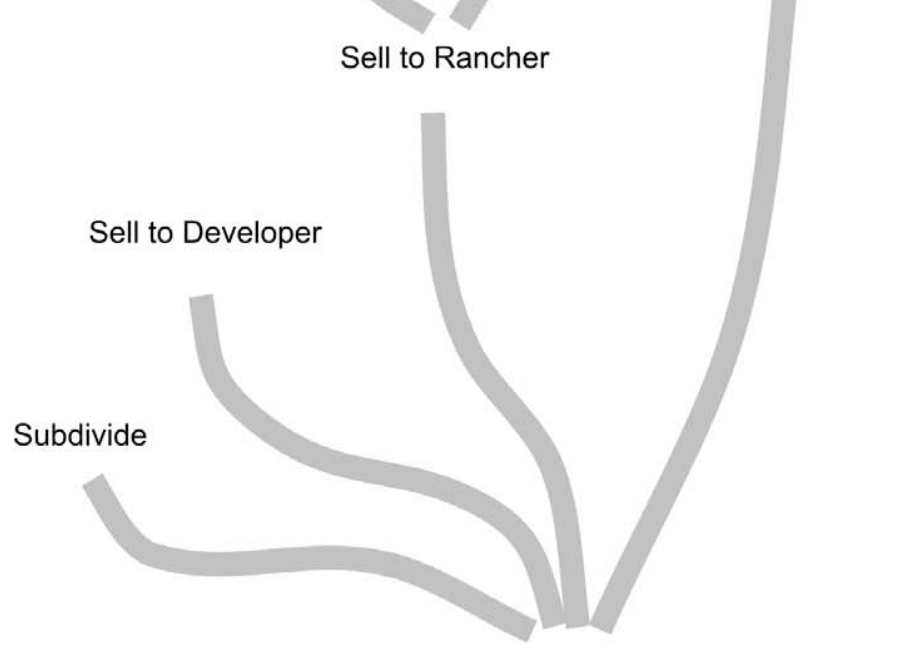

SELL THE RANCH

SELL THE RANCH
Retain grazing rights on large lots; Continue to own and manage ranch

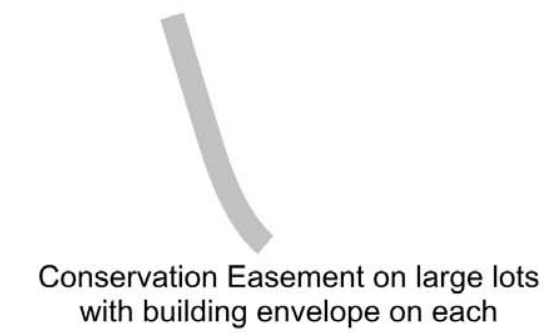

Family home sites and substantial subdivision

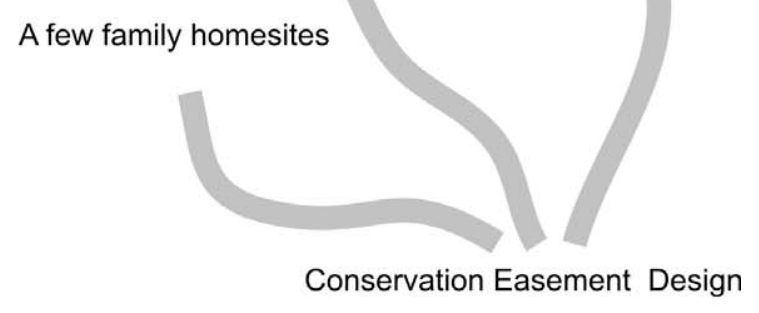

Subdivide Some Land

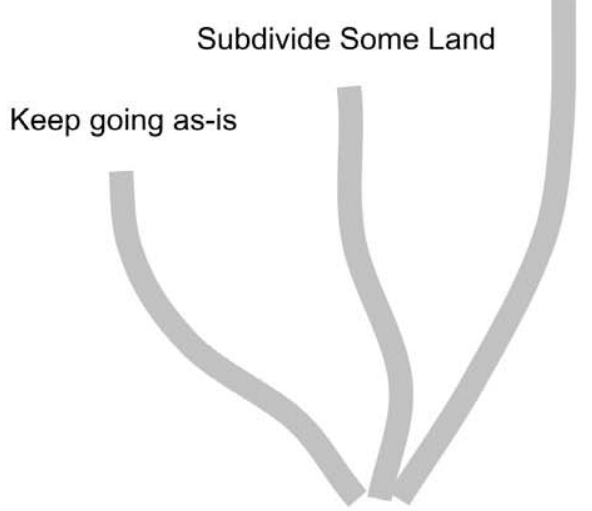

KEEP THE RANCH
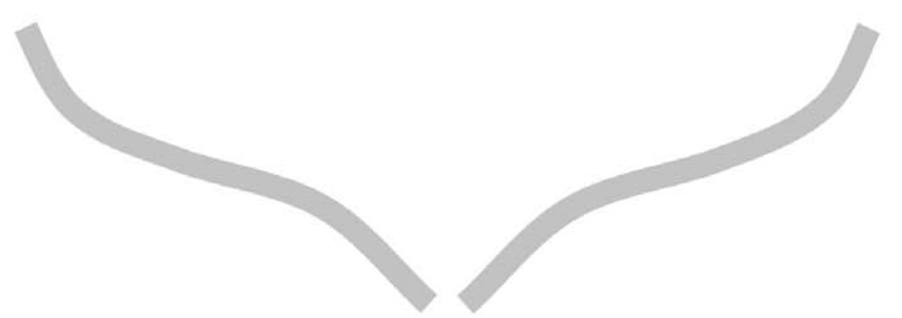

\section{DECISION TREE}

Figure 2. Today there are a lot of options for ranch families seeking to access the capital tied up in ranchland and/or to protect their ranchland for future generations. Conservation easements are a valuable tool and can be used in a number of different ways.

nificant agricultural, open space, ecological, historic, and/or recreational values. Unlike road or power-line easements, these deeds prevent certain land uses from happening.
The voluntary donation of a conservation easement in perpetuity to a 501(c)(3) nonprofit organization (land trust) or a unit of government is a tax-deductible charitable gift under 
Table 2. Conservation Development Scenarios

\section{Scenario 1}

Entire ranch, including 7 lots and ranch headquarters, is placed under a conservation easement. 32,000 acres.

Before value (\$150/acre)

$\$ 4,800,000$

After value (\$75/acre)

Easement value

$\$ 2,400,000$

Sale price of lots $(\$ 400 /$ acre $)$

$\$ 2,400,000$

$\$ 2,000,000$

\section{Scenario 2}

Ranch, excluding lots (5,000 acres) and ranch headquarters (5,000 acres), is placed under a conservation easement. 32,000 acres $-10,000$ acres $=22,000$ acres

Before value (22,000 acres)

After value $(22,000$ acres $)$

Easement value

Less enhancement (10,000 acres)

Easement value

Sale price of lots $\left(\$ 500 /\right.$ acre $\left.{ }^{\star}\right)$

$\$ 3,300,000$

$\$ 1,650,000$

$\$ 1,650,000$

$(\$ 500,000)$

$\$ 1,150,000$

$\$ 2,500,000$

*Value of lots increases to $\$ 500 /$ acre because of potential tax benefit to buyer who would donate a conservation easement on their land.

\section{Scenario 3}

Ranch and 7 lots (excluding ranch headquarters [5,000 acres]) are placed under a conservation easement. 32,000 acres $-5,000$ acres $=27,000$ acres.

Before value $(27,000$ acres $)$ $\$ 4,050,000$

After value $(27,000$ acres)

Easement value

Less enhancement $(5,000$ acres)

Easement value

Sale price of lots $(\$ 400 /$ acre $)$

$\underline{\$ 2,025,000}$

$\$ 2,025,000$

$(\$ 250,000)$

$\$ 1,775,000$

$\$ 2,000,000$

\section{Scenario 4}

Only 7 lots (5,000 acres) and view shed (5,000 acres) are placed under a conservation easement. Total: 10,000 acres.

Before value (10,000 acres)

After value (10,000 acres)

Easement value

Less enhancement $(22,000$ acres $)$

Easement value

Sale price of lots $\left(\$ 300 / a c r e^{\star}\right)$

*Value of lots decreases to $\$ 300 /$ acre because of less land being protected.

In this scenario the easement donation ends up having no value due to the enhancement of the value of the part of the ranch that is not placed under the easement. 
Table 2. (continued)

\section{Scenario 5}

Only the view shed $(5,000$ acres) is placed under a conservation easement.

32,000 acres $-5,000$ acres $=27,000$ acres.

Before value (5,000 acres)

$\$ 750,000$

After value $(5,000$ acres $)$

Easement value

Less enhancement (27,000 acres)

Easement value

Sale price of lots $\left(\$ 300 /\right.$ acre $\left.{ }^{\star}\right)$

$\$ 375,000$

$\$ 375,000$

$\underline{(\$ 1,350,000)}$

$(\$ 975,000)$

$\$ 1,500,000$

*Value of lots decreases to $\$ 300 /$ acre because of less land being protected.

In this scenario, the easement donation also ends up having no value because of the enhancement of the value of the part of the ranch that is not placed under the easement.

Section 170(h) of the Internal Revenue Service (IRS) codes. The value of the easement gift is appraised using a "before and after" method. The land's value for development before the easement is compared to its value afterward-the difference is the value of the easement donation. An easement does not "freeze" the value of the land-the rancher can always sell it for whatever price someone is willing to pay, but the new owner must honor the terms of the easement. The Pension Protection Act of 2006 greatly expanded the federal income tax benefits for easement donations. For qualifying ranchers and farmers (earning more than half their income from agriculture), an individual owner can deduct the value of the donation up to $100 \%$ of their adjusted gross income (AGI) over a 16-year period. Tax savings depend on the value of the easement and the rancher's AGI. Corporate ag owners can deduct up to $100 \%$ of their taxable income for 16 years. For nonqualifying owners, those earning a smaller proportion of their income from agriculture, the deduction drops to a maximum of $50 \%$ of their AGI. These existing incentives apply until December 31, 2007, unless they are renewed. As with any tax matter, professional financial and legal advice should always be sought before proceeding. For updated information check the Web site of America's top easement tax specialist at http://www.stevesmall.com.

As the donor's income and the easement's value rise, tax savings typically increase (Table 1). Nonqualifying landowners (earning less than half their income from agriculture) usually receive lower benefits. Some states also have an income tax credit available for easement donations that further sweetens the pot.

Conservation easements can also be sold by the rancher if a nonprofit group or agency the rancher respects has the funds. States such as California, Colorado, and Florida have annual funding for this, others do not. The Federal Farm and Ranch Lands Protection Program of the NRCS can provide part of the cash with the remainder coming from other sources such as a land trust, lottery proceeds, sales tax, or open space bond issue. In all cases, income from the sale is taxed as a capital gain.

At present, estate tax benefits may be substantial for easement donations. In 2007 and 2008, estates of $\$ 2$ million or less are exempt with the remainder taxed at a rate as high as $46 \%$. In 2009 , the exemption rises to $\$ 3.5$ million. In 2010 , the IRS gets nothing. After that, federal estate taxes vanish unless Congress puts them back on the books.

Property taxes are typically unaffected by a conservation easement. Land that was taxed as "agriculture" before the easement will remain in that category.

\section{The Rancher's Choices}

If you are a rancher, the best way to maintain control of your destiny is to be clear about your goals and understand all your options. The rancher must ask some tough questions: If the children inherited the ranch today, what would the tax bill be? How would it be paid? Who will manage the ranch after the rancher is gone? What does the rancher want the ranch to look like 100 years from now? The answers to these questions are personal and private. They are between the rancher and ranch family but there are now allies in agricultural organizations and land trusts that can help ranchers achieve their goals.

The "decision tree" (Fig. 2) illustrates how conservation easements create options for ranch families in meeting a wide range of financial and personal needs. For example, if a rancher chooses to sell the ranch, there are many options. Each involves individual values. If the rancher is interested primarily in getting as much money out of the land as possible, the ranch can be subdivided into as many lots as possible or sold to a conventional developer. A conventional developer can also subdivide the ranch for you. If, instead, the rancher prefers to see the land stay a ranch and to stay in ranching forever, a conservation easement can be placed on it-and 


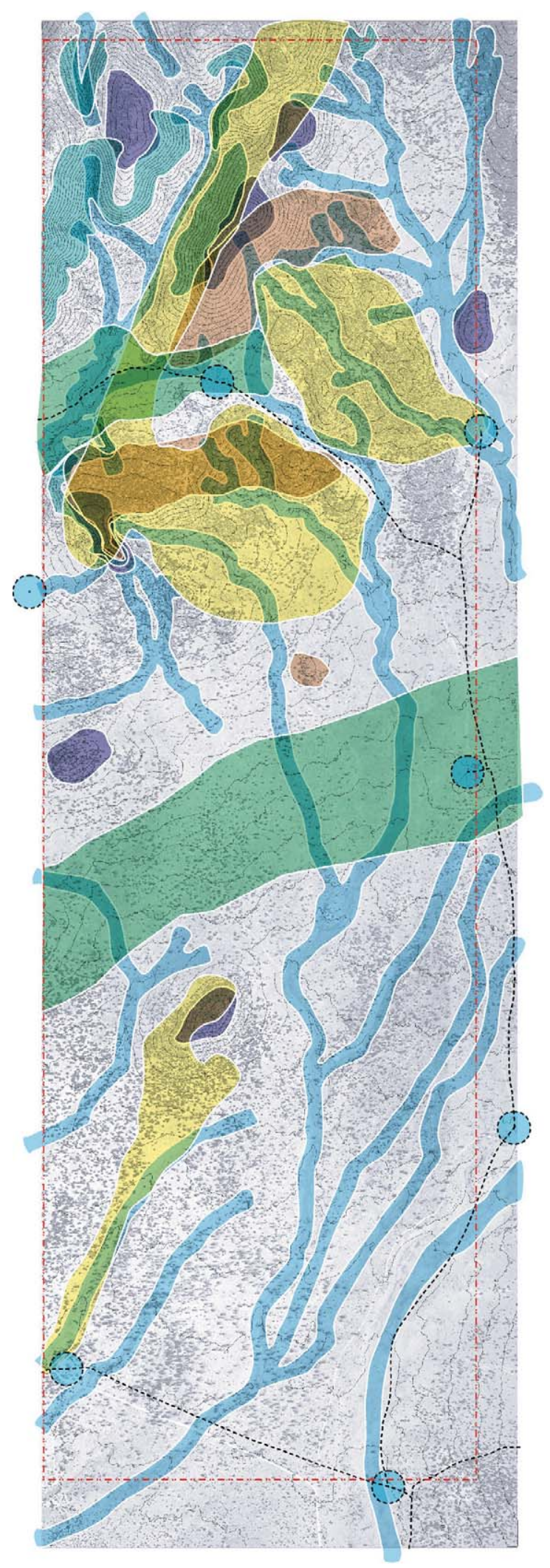

Figure 3. If part of the ranch is going to be developed or subdivided, mapping of resources should be used to plan building sites, lot lines, and roads for minimum impact on things like waterways, view shed, and wildlife habitat. then the land can be sold to another rancher or "conservation buyer" who is interested in the beauty of the place. If the ranch is sold with no conservation easement on it-even to another rancher-there is a risk that the land will be subdivided in the future. The most obvious disadvantage of selling the ranch is losing control of the land.

If the rancher chooses to keep the ranch, there are several choices. Some ranchland can be subdivided-based on either the conventional or the conservation development pattern. If the rancher needs to raise some money or get some money out of the land but does not want to see the land heavily subdivided, a conservation easement can be placed on the land while the rancher retains limited development rights. These limited development rights can range from a few family homesites to multiple large lots with designated building envelopes where the rancher retains the grazing rights. Various hybrids of development can be designed to meet financial goals while protecting and retaining rancher control over ranch management.

Conservation easements and conservation development work because they put the market to work for the ranchers by capturing the value of conservation in the real estate market as a commodity. In addition to the "commodity production" value and recreational (eg, hunting) value, land has a conservation value. This is true whether a rancher chooses to develop all, part, or none of the ranch. For example, if the rancher decides to keep the ranch just like it is, the ranch still has a builtin development value. Population pressure will only increase this value. Usually, unless you develop your land, you will not be able to capture this value. The one exception is a conservation easement.

All this can be confusing for ranchers who are used to valuing land on the basis of its capacity to produce cattle. It can also be confusing for the developer who is used to seeing land only as a marketable commodity. In addition to the "commodity-production" and "residential" value, land has a "conservation" value. But how is this conservation value appraised? How can ranchers capitalize on it? How can land developers factor it into their projects? And how can conservation easement design help create this value while protecting the land? Capitalizing on this value starts by looking at the land.

\section{Sieve Mapping and Conservation Development}

Sieve mapping is a design process that allows the rancher to capture the conservation value of the land and put it to work for the benefit of the ranch. Maps are made of prime soils, wildlife habitat, water features, historic sites, scenic views, and other important conservation priorities. These maps are overlaid into a composite of conservation priorities, and the land that "falls through the sieve" is the land that is most appropriate for development. It is important to note that this is also the land whose value is most enhanced by what is protected. Figure 3 illustrates this composite. Sieve mapping 


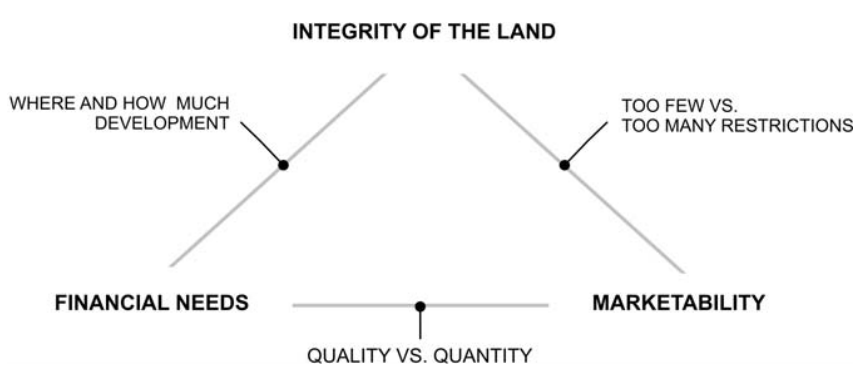

Figure 4. Conservation development offers a compromise to the rancher and the buyer. The amount and type of development should consider the financial needs of the family, the marketability of the product, and the integrity of the land.

works because buyers prefer land that is adjacent to protected open space and are willing to pay a premium for it. This insight is the basis for identifying and then capitalizing on the economic value of land conservation in the marketplace.

Conservation development is based on the long-term creation of real property value premised on land protection as a value-adding principle that appreciates over time. The crux of conservation development is balancing land development with land protection. This balance has to do not only with where development is appropriate (as determined through sieve mapping) but also with how much development is reasonable. Only the landowning ranch family can decide how much development achieves the family's goals. Figure 4 illustrates the factors that influence this balance.

\section{The Montosa Ranch Project}

The Montosa Ranch, located near Magdalena, New Mexico, is co-owned and managed by B.W. and Billie Cox (Photo 1). Because their wealth is tied up in land, the owners needed to get some equity out of the place. They first considered developing 2,000 acres into 20- to 40-acre lots but rejected the idea-too many neighbors. B.W. explained his emotional attachment to the land: "I consider myself to be the luckiest person in the world to be able to live and work in God's creation on the Montosa Ranch. I want the ranch to be protected so that it looks like this for the next 50 generations and beyond. I want the land left as it is. I don't want to see the kind of subdivisions that are being developed around Datil on this land. I want other people to see that nature can be managed for the future, and that it doesn't have to be abused."

Still, when the idea of a conservation easement was presented to B.W., he was hesitant. The word "perpetuity" scared him. "I don't have all the answers for the best way to manage the ranch for the future," B.W. said at the time, "but I want to keep my options open. Forever is a long time. I don't want to be cursed by future generations for a wrongheaded decision I may make today."

B.W. and Billie's financial partner was also reluctant to consider a conservation easement. It sounded like "tree hugging" to him. However, the ranch's attorney, John Garrett, was open to the idea. "Why be against it," John asked, "if it can satisfy your financial goals and do some greater good?"

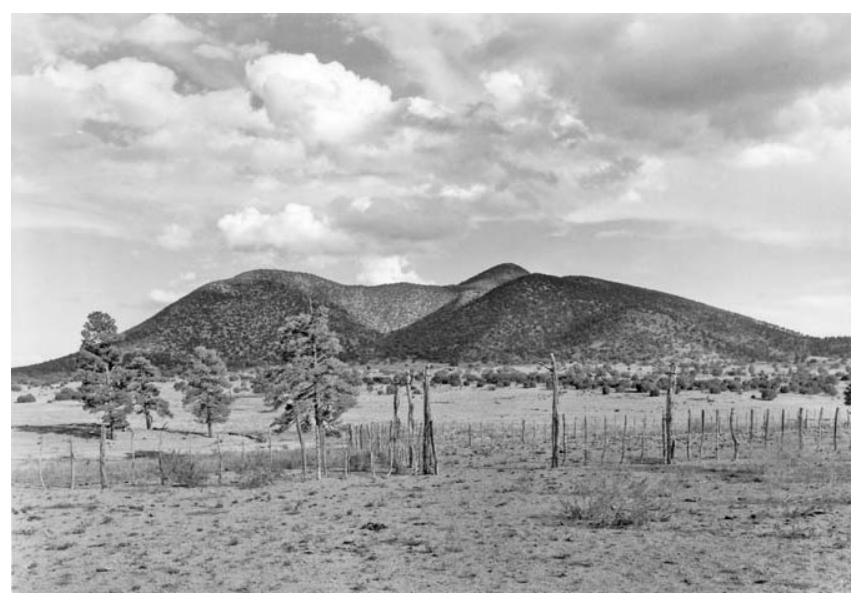

Photo 1. Pasture fences and Tres Montosas Mountain, Montosa Ranch, New Mexico. Photo by Edward Ranney.

Two critical questions emerged: How do you maximize the market value of a limited number of lots without also providing open space amenities to the lot buyers? And how do you develop those lots in a way that will not adversely affect the ranch?

To help the owners make an informed decision, the financial and tax implications of several different scenarios were analyzed (Table 2). Using hypothetical numbers, the scenarios were based on the following assumptions:

1) Total area of ranch: 32,000 deeded acres

2) Total area of 7 lots to be sold: 5,000 deeded acres

3) Total area of view shed as seen from lots: 5,000 deeded acres

4) Total area of ranch headquarters: 5,000 deeded acres

5) Before value of ranch, unencumbered by easement: \$150/acre

6) After value of ranch, easement encumbering all of ranch: $\$ 75 /$ acre

7) Value of lots, if lots and entire ranch are under easement: $\$ 400 /$ acre

8) Value of lots, if entire ranch but not lots are under easement: $\$ 500 /$ acre

(Note: value increases because of potential tax benefit to buyer.)

9) Value of lots, if only lots and view shed are under easement: \$300/acre

(Note: value decreases because less land is being protected.)

10) Enhancement of portion of ranch not under easement: $\$ 50 /$ acre

In the end, the owners decided on scenario 3: to place most of the ranch $-27,000$ of the 32,000 deeded acres - under a conservation easement. The sale price of the lots under the easement is less than the example of scenario 2 , but the conservation easement prevents further subdivision. The land trust holding the easement bears the expense for enforcing its terms instead of the ranch owners. And by keeping the 
ranch headquarters out of the easement, the ranch owners have hedged their bets for future land sales.

The Montosa Ranch Project is about capturing the conservation value of the land for the benefit of the ranch owners. The project protected thousands of acres of private land that will continue to be ranched. It establishes a powerful model for others to consider.

\section{Conclusion}

Conservation easements and conservation development honor one of America's great strengths: private property rights. They support the stewardship of ranchers while allowing them to capitalize on this contribution. The approach creates income possibilities through limited development and allows a family to pay off debt while preserving the integrity of the land. Conservation easements are one of the last best chances for ranchers to maintain their way of life.

Authors are Professor of Geography, 104 Breland Hall, PO Box MSC MAP, New Mexico State University, Las Cruces, NM 88003-8001, jowright@nmsu.edu (Wright); and Architect, ALA, 103 Dartmouth Drive SE, Albuquerque, NM 87106 (Anella).

\section{References}

1. Anella, A., And J. B. Wright. 2004. Saving the ranch: Conservation easement design in the American West. Washington, DC: Island Press. 176 p.

2. Liffmann, R., L. Huntsinger, and L. Forero. 2000. To ranch or not to ranch: home on the urban range? Journal of Range Management 53(4)362-370. 